\title{
Water Use Efficiency and Eco-Niche-Yield Prediction of Rainfed Wheat in China's Loess Plateau
}

\author{
Qianying Pan \\ Foreign Languages College, Anhui Polytechnic University \\ Wuhu 241000, Anhui, China \\ Food Crop Science Department, Cotton Research Institute \\ Shanxi Agriculture Science Academy, Yuncheng 044000, Shanxi, China \\ Xinglai Pan (Corresponding author) \& Foyou Yang \\ Food Crop Science Department, Cotton Research Institute \\ Shanxi Agriculture Science Academy, Yuncheng 044000, Shanxi, China \\ Tel: 86-359-216-5899Ｅ-mail: pxlwbig@126.com \\ Xuefei Wen \& Fei Pei \\ Foreign Languages College, Anhui Polytechnic University \\ Wuhu 241000, Anhui, China \\ Sirui Pan, Tianyuan Pan \& Yinhong Shi \\ Food Crop Science Department, Cotton Research Institute \\ Shanxi Agriculture Science Academy, Yuncheng 044000, Shanxi, China
}

Received: April 29, $2011 \quad$ Accepted: May 12, $2011 \quad$ Online Published: December 1, 2011

doi:10.5539/jas.v4n1p143

URL: http://dx.doi.org/10.5539/jas.v4n1p143

Funding: supported in part by nyhyzx07-002 (3-2) and NSFC30971786.

\begin{abstract}
A twenty-three year study of water use efficiency and related parameters on a 0.44 ha. rainfed wheat field resulted in the following new data: Yield averaged 2135.13 $\pm \sigma 841.08$ (minimum 810 maximum $3923 \mathrm{kgha}^{-1}$ ); Water Use Efficiency $(\mathrm{Y} / \mathrm{ET})=6.23 \pm 2.06\left(2.84 \sim 10.21 \mathrm{kgha}^{-1} \mathrm{~mm}^{-1}\right)$; Precipitation during the fallow period $=$ $301.7 \pm 107.6(129.8 \sim 498.2 \mathrm{~mm})$; Water storage in $5 \sim 210 \mathrm{~cm}$ soil layer at about sowing $=328.41 \pm 78.72$ (177.3 453.8 mm); Soil evaporation during the fallow period $=195 \pm 60.14(72.6 \sim 347.1 \mathrm{~mm})$; Precipitation storage $=106.7 \pm 66.3(-22 \sim 234.2 \mathrm{~mm})$; Precipitation storage efficiency $\%=32.61 \pm 16.22(-16.9 \sim 53.3)$; Precipitation during the growing season $=234.6 \pm 57.39(139.8 \sim 400.6 \mathrm{~mm})$; Precipitation in May $=54.91 \pm 38.69$ $(8.8 \sim 142.1 \mathrm{~mm})$; Water storage in $5 \sim 210 \mathrm{~cm}$ soil layer just after harvest averaged 220.35 $446.15(123.3 \sim 335.3$ $\mathrm{mm})$; EvapoTranspiration during the growing season averaged 342.6 284.29 (220.5 586.6 mm). WUE benchmarks were proposed for the first time to the region as follows: $\geq 5 \mathrm{kgha}^{-1} \mathrm{~mm}^{-1}$ for very poor and poor years; $\geq 9 \mathrm{kgha}^{-1} \mathrm{~mm}^{-1}$ for medium and good years; and $\geq 12 \mathrm{kgha}^{-1} \mathrm{~mm}^{-1}$ for excellent years. A novel model using precipitation and soil parameters before sowing was well correlated with yields. Using the first digital clustered five eco-niche-yield types and based on the model predictions, management recommendations beforehand may help growers to approach the eco-niche-yield potentials with rational input.
\end{abstract}

Keywords: Draught stress, Soil moisture, Precipitation storage, Evapotranspiration, Decision supporting, Modeling 


\section{Introduction}

Located on the first platform at the southeast end of the Loess Plateau, Yuncheng prefecture is believed to be the cradle of Chinese traditional agriculture civilization. Winter wheat-summer fallow has been the predominant rainfed staple food crop production system in this region for hundreds of years. Farmers in this region are considered as the best practitioners of careful and intensive cultivation that has the goal of maximum water infiltration and storage in drylands. Even though farmer's input level increasing steadily year by year, rainfed wheat yield varies significantly year from year. Draught stress is, of course, the greatest constraint on wheat yield in this region. According to the records of eight carved stone inscriptions (see two of them in Fig.1) and the disaster relief diary of Timothy Richard (Soothill, 1924), in 1877 an unprecedented deadly drought disaster occurred in this region. There was not even a drop of rainfall between March of 1877 and March (Chinese lunar calendar) of 1878. Although the drought was unusually severe, it is an indication of the potential rainfall variability in the region.

Farmers now grow about 200,000 ha rainfed wheat in this region. Farmer experience and scientific research indicate that the loess soils are deep and able to store large amounts of water and that the dryland winter-wheat crop relies heavily on use of water stored in the deep subsoil. But a number of important research questions remain for the region: a) How efficient is the soil storage of precipitation? b) How much water infiltrates into and stored in the soil, and how much is lost by evaporation from the soil and transpiration from the plant? c) How much of the available water stored in the soil is converted into wheat yield? And d) How can we predict the eco-niche-yield before sowing and/or any following key management stages, for successful planning and practicing?

We conducted a case study from 1982 to 2009 in a trial land at Beizhang village, Linyi County, Yuncheng prefecture, Shanxi province, China, with a number of goals. This report focuses on the water use efficiency and on the prediction of eco-niche-yield of rainfed wheat grown using the practices of local farmers. We try to develop a method that integrates modeling technic and local indigenous knowledge, to help farmers for input-efficient and high and stable yield in varying draught stress year-types.

\section{Materials and Methods}

\subsection{Location}

BeiZhang village is located at the cross section of about $34^{\circ} 42^{\prime} \mathrm{N}$ and $110^{\circ} 37^{\prime} \mathrm{E}$, with the altitude about $530 \mathrm{~m}$. The trial land was $220 \mathrm{~m}$ in length $(\mathrm{E}-\mathrm{W})$ and $20 \mathrm{~m}$ in width $(\mathrm{S}-\mathrm{N})=4400 \mathrm{~m}^{2}=0.44$ ha (approximately 6.6 Chinese $m u$ ) with a slope less than $2 \%$, and runoff occurring only when the rainfall intensity was greater than $100 \mathrm{~mm} \mathrm{hr}^{-1}$. The land has been cultivated for hundreds years and is a typical dryland. The soil is a light loess loam ("yuan huang lu tu" in Chinese). Soil profile bulk density ranged from 1.23 to $1.43 \mathrm{~g} \mathrm{~cm}^{-3}$ (Fig.2).

\subsection{Weather}

According to the Linyi county weather observatory station ( $55 \mathrm{~km}$ away from the site) records, the mean annual precipitation was $496.5 \mathrm{~mm}$, with the maximum $849.8 \mathrm{~mm}$ in 1958 and the minimum $323.1 \mathrm{~mm}$ in 1977 , with $52 \%$ of the precipitation occurring in July, August and September; the mean annual pan evaporation was 2116.9 $\mathrm{mm}$; the mean annual sunshine hour was $2362 \mathrm{hr}$; the mean annual temperature was $13.5^{\circ} \mathrm{C}$, with the maximum $42.8^{\circ} \mathrm{C}$ occurring in June, 1966 , and the lowest $-17^{\circ} \mathrm{C}$ occurring in January, 1967; with 224 mean annual frost free days.

\subsection{Wheat cultivars}

The wheat cultivars used for the experiment were Beijing 12057 from 1981 to 1989, Yun 78-2 from 1990 to 1994 , Jinmai 47 from 1995 to 2005, and Linhan 536 from 2006 to 2009.

\subsection{Management practices}

In consideration of the protracted nature of the follow-up investigation, and the progress of the regional wheat productivity, we let the owner of the trial land do whatever the management practices as the farmers usually do in this region each crop year. Let him go with the flow. Planting dates occurred from the end of September to early October. Harvesting dates occurred from the end of May to early June.

\subsection{Measurements}

Precipitation was recorded from July 1978 to July 2010 using a rain gauge installed approximately $200 \mathrm{~m}$ away from the experimental field. 
Soil gravimetric water content was measured in $10 \mathrm{~cm}$ increments from $5 \mathrm{~cm}$ to $100 \mathrm{~cm}$ depth and in $20 \mathrm{~cm}$ increments from $100 \mathrm{~cm}$ to $200 \mathrm{~cm}$ depth using gravimetric procedures. Soils were sampled a few days before planting in late September and just after harvest in early June of the following year.

Gravimetric water content $(\%) \equiv \mathbf{G w c}=(($ weight of wet soil subsample - weight of dry soil subsample)/weight of dry soil subsample)*100.

Soil water storage content was determined to a depth of $210 \mathrm{~cm}$ because the wheat root system usually reaches to about such a depth and contributed much to the grain yield (Pan, 1982; Li, 1983; Pan et al. 1997a).

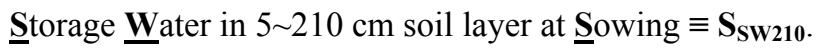

Storage Water in $5 \sim 210 \mathrm{~cm}$ soil layer just after $\underline{\text { Harvest }} \equiv \mathbf{H}_{\mathbf{S w 2 1 0}}$.

$\mathbf{S}_{\mathrm{SW} 210}$ or $\mathbf{H}_{\mathrm{Sw} 210}=$ Sum of $\mathbf{G w c}$ bulk density $\left(\mathrm{gcm}^{-3}\right) *$ depth of sampling $(\mathrm{cm}) / 0.1 \mathrm{gcm}^{-2} \mathrm{~mm}^{-1}$

Soil Evaporation during the fallow period $\equiv \mathbf{E}_{\mathrm{F}}=\mathbf{P}_{\mathrm{F}}-\left(\mathbf{S}_{\mathrm{SW}_{210}}-\mathbf{H}_{\mathrm{SW} 210}\right)_{\text {CalendarYear }}$

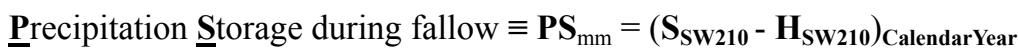

$$
\mathbf{P S E}_{\%}=\mathbf{P S}_{\mathbf{m m}} / \mathbf{P}_{\mathbf{F}} * 100
$$

EvapoTranspiration during growing season $\equiv \mathbf{E T}=\left(\mathbf{S}_{\mathbf{S W 2 1 0}}-\mathbf{H}_{\mathbf{S W} 210}\right)_{\text {CropYear }}+\mathbf{P}_{\mathbf{G}}$

(Where $\mathbf{P}_{\mathbf{F}}=$ Precipitation during the Fallow period, $\mathbf{P}_{\mathbf{G}}=$ Precipitation during the Growing season)

Grain was harvested using either a traditional reaping and threshing procedure, or with a commercial combine. Grain was air dried in the sun to about $13 \%$ water content and weighed on a digital scale accurate to $500 \mathrm{~g}$.

Yield $=$ Total grain weight/0.44 ha.

\section{Water Use Efficiency $=$ Yield $/$ ET $=\mathbf{W U E}_{Y / E T} \equiv \mathbf{W U E}$}

Strictly speaking, water use is the water used and transpired by the wheat itself during the growing season. We used soil and precipitation information to estimate ET, which includes both the water lost through evaporation from the soil and transpiration loss. Although this calculation includes the water that the wheat crop cannot access and thus underestimates the real water use efficiency, it provides a means to compare water use in different years.

\section{Results}

The measured data and calculated parameters with depth and/or with time are presented in Figures 2, 3, 4, 5 and Table 1.

1). About $52 \%$ of the annual precipitation occurred during the fallow period and the peak of annual precipitation was between July and September (Fig.2).

2). The average soil bulk density was $1.33 \mathrm{~g} \mathrm{~cm}^{-3}$, with a slightly denser illuviation layer at about $50 \mathrm{~cm}$ depth (Fig.3), typical of region's soils (Soils in Yuncheng prefecture, 1986).

Using the data presented in Figures 3, 4, and 5, $\mathrm{S}_{\mathrm{Sw} 210}$ and $\mathrm{H}_{\mathrm{SW} 210}$ were calculated. Although there was a large variation with depth and time, the average soil gravimetric water content $(10 \sim 200 \mathrm{~cm})$ for the 23 crop years was $13.7 \%$ at sowing, and $8.8 \%$ after harvest. Rainfall greater than $100 \mathrm{~mm}$ in May could increase the soil gravimetric water content considerably to a depth of $60 \mathrm{~cm}$ such as in $2009(142.1 \mathrm{~mm}), 1999(106.6 \mathrm{~mm}), 1998$ $(140.5 \mathrm{~mm})$ and $1983(134.1 \mathrm{~mm})\left(\mathrm{P}_{\mathrm{M}}\right.$ in Table 1, arrowed years in Fig. 5). The critical growth stages of flowering, grain set, grain filling and maturing are all in the May, all need both rainfall and sunshine. Too much rain with low amounts of sunshine in May, not only reduces the yield through less evapotranspiration and photosynthesis, but also increases the swelling of roots in upper soils (Pan, 1982).

3). $\mathrm{PS}_{\mathrm{mm}}$ ranged from $-22 \mathrm{~mm}$ to $234.2 \mathrm{~mm}$. $\mathrm{PSE}_{\%}$ ranged from $-16.9 \%$ to $53.2 \%$. $\mathrm{PSE}_{\%}$ Averaged $32.61 \%$. It confirmed again that about $60 \%$ of precipitation during fallow period was lost through soil evaporation (runoff was estimated to be small during this time because the trial land is $30 \mathrm{~cm}$ high ridged at the 4 side edges). How to have the precious $\mathrm{P}_{\mathrm{F}}$ got into the soil as faster and deeper as possible is a big challenge to the modern technology. Building "Nutrient Columns" (Pan et al., 1997b) and drilling "Soil Holes" (Xiao et al. 1986) demonstrated dramatic benefits but need mechanization. Increasing soil organic matter would certainly help because of its positive effects on soil structure and keeping soils more open to accept and maintain rainfall (Fred Magdoff, 1993).

4). WUE ranged from 2.84 to $10.21 \mathrm{kgha}^{-1} \mathrm{~mm}^{-1}$, averaged $6.23 \mathrm{~kg} \mathrm{ha}^{-1} \mathrm{~mm}^{-1}$. This is about $3.6 \mathrm{kgha}^{-1} \mathrm{~mm}^{-1}$ lower than the $9.8 \mathrm{kgha}^{-1} \mathrm{~mm}^{-1}$ estimated by Sadras's (2006) for the China loess plateau. The skewness (0.415) is also 
larger than Sadras's (0.16). There are probably two reasons for the differences: a) yields in this study were from a 0.44 ha grower's field rather than small experimental plots; and b) we used the actual measured ET instead of the reference ET.

Comparison between years indicates that while WUE was positively correlated with yields, higher yield did not always correspond to higher WUE. For example, in 1984 the yield was $1658 \mathrm{kgha}^{-1}$ and the WUE was 3.29, while the 2009 yield was only $960 \mathrm{kgha}^{-1}$, but with WUE was higher, $4.21 ; 1989$ yielded $3263 \mathrm{kgha}^{-1}$ with WUE of 9.39, 2004 yielded $3563 \mathrm{kgha}^{-1}$ with lower WUE 6.07. It proves that WUE can also be used as a criterion for evaluating the degree of farmer skill at rainfed wheat production management. Here we set the benchmarking WUE as: $\geq 5 \mathrm{kgha}^{-1} \mathrm{~mm}^{-1}$ for poor eco-niche-yield years, $\geq 9 \mathrm{kgha}^{-1} \mathrm{~mm}^{-1}$ for medium and good eco-niche-yield years, and $\geq 12 \mathrm{kgha}^{-1} \mathrm{~mm}^{-1}$ for very good or excellent eco-niche-yield years, which will be useful for the region to guide and evaluate its wheat production in the coming years.

5). Using cluster analysis we identified five eco-niche-yield types as indicated in Fig.6. Yield less than $1500 \mathrm{~kg}$ $\mathrm{ha}^{-1}$ is a very bad year. Yield in between 1500 2250 $\mathrm{kgha}^{-1}$ is a bad year. Yield in between 2250 3000 $\mathrm{kgha}^{-1}$ is an average or medium year. Yield in between $3000 \sim 3750 \mathrm{kgha}^{-1}$ is a good year. Yield greater than $3750 \mathrm{kgha}^{-1}$ is a very good or excellent year.

6). Fig.7 shows calculated grain yield as a function of the $\mathrm{P}_{\mathrm{F}}, \mathrm{S}_{\mathrm{SW} 210}, \mathrm{E}_{\mathrm{F}}$, and $\mathrm{PS}_{\mathrm{mm}}$. We can use this model to predict the eco-niche-yield before sowing, it does have paramount importance for management planning and recommendations. For example, a) for a predicted poor eco-niche-yield, application of $100 \mathrm{kgha}^{-1}$ urea (or an equal amount of $\mathrm{N}$ from another source) would be suggested before sowing, if the precipitation from sowing to mid December is much better than the normal year, additional $35 \mathrm{kgha}^{-1}$ urea top dressing in late December with the traditional tillage practices will be suggested; b) for a good eco-niche-yield, $200 \mathrm{kgha}^{-1}$ urea (or equal N) before sowing will be suggested, if the precipitation from sowing to mid December is much better than the normal year, additional $50 \mathrm{kgha}^{-1}$ urea top dressing will be suggested again; c) for a predicted excellent eco-niche-yield, 230 250 $\mathrm{kgha}^{-1}$ urea before sowing will be suggested. We are to be able in this way to reduce the growers input risks, because years' experiences have taught us that: too much nitrogen fertilizer in a bad year resulted haying-off (Angus et al., 2001) that not only wastes the fertilizers but also gives much less yield than less nitrogen fertilizer; while conservative application of nitrogen fertilizer in good years could not reach the attainable yield that of course lost the good chances.

\section{Discussions}

\subsection{Twenty-three years' WUE and Three WUE benchmarks}

Twenty-three years WUE ranged from 2.84 to $10.21 \mathrm{kgha}^{-1} \mathrm{~mm}^{-1}$, averaged $6.23 \mathrm{kgha}^{-1} \mathrm{~mm}^{-1}$. The three WUE benchmarks are: $\geq 5 \mathrm{kgha}^{-1} \mathrm{~mm}^{-1}$ for poor years; $\geq 9 \mathrm{kgha}^{-1} \mathrm{~mm}^{-1}$ for medium and good years; and $\geq 12 \mathrm{kgha}^{-1} \mathrm{~mm}^{-1}$ for the excellent years.

It is obvious that WUE depends on both the amount and the distribution of the rainfall itself. However, advisers can always make sure that if the WUE is smaller than the benchmark WUE in a given eco-niche-yield type, there must be some other constraint problems in addition to the given weather conditions. The results and the other new data may also serve as a case to be compared studies of other regions global rainfed agriculture.

\subsection{Five eco-niche-yield year types and model prediction before sowing}

Rainfed wheat yield varies year from year, even though farmer's input level increasing steadily year by year. A good forecast of the eco-niche-yield year type before sowing, is an important decision-making basis both for better output with rational input and for environment-friendship. Combining with the experienced-farmers' perceives, the experimental equation based on 23 year's data of the case study, had done very well for the past 3 years' eco-niche-yield predictions, for the $\sim 200,000$ ha rainfed wheat in YunCheng prefecture. Before sowing in 2006, the prototype of this model gave the expected yield for 2007, we changed the calculated yield value into a fuzzy value $=$ average year type, combining with several experienced farmers' perceives, we predicted that 2007 would most likely be an average year to a bad year. And Yuncheng prefecture did have bad wheat yield in 2007. Then we incorporated all the data of the trial land already obtained in 2007 into the model, and had a revised model for prediction of 2008 as an average to good year type. Again the prefecture did have an average wheat yield in 2008. So we did for 2009 as a very bad year type, it did prove the fact once again. We are confident with this "exact-fuzzy-accurate" step-wise predicting method.

Optimizing wheat production management within a small geo-ecological region of similar land attributes and soil properties is our base aim. However, optimum productivity is a continually moving target that requires step-wise moving methodologies because of the variations in climatic as well as technical and social features. We 
thought that 3 to 5 trial lands within an eco-niche range might give a much more accurate model. Therefore improved follow-up investigations have begun in 2009 for continually improvement of the model.

Anyway, varieties of tolerance and lower level of fertilizer input for very bad and bad years, varieties of stable yield and average level of fertilizer input for average and good years, varieties of higher yield potential and higher level of fertilizer input for good and excellent years, are all the best countermeasures to reach the highest water use efficiency. We hope more accurate model predictions can help farmers take a few simple precautions to increase their input/output ratios of rainfed wheat in a given eco-niche.

\subsection{Logos for better crop production management}

Drought disasters have a long history in China and elsewhere, Draughts cause more grain loss in China than any other type of natural disaster, and draught stress is still the biggest challenge in the $21^{\text {st }}$ century. Keeping this in mind, we sum up the logos for successful crop production in Chinese as shown in Fig.8.

We try to end this paper by translating the logos as following:

Crop production is to exploit and utilize all the available resources, take measures to increase the system's potential and decrease any possible losses, finally to sustainably obtain higher and healthier outcomes with less input and less environment-degradation.

Crop production rules should be: Observe the weather, Observe the soils, and Observe the living things; Knowing one's available production techniques and means, knowing their attributes and properties, and knowing the consequences of your practices; Ponder prudently, pre-plan carefully, and get everything ready and take measures beforehand; Use both general and local knowledge and your own sense to evaluate and re-evaluate your methods before and after the season; Following the appropriateness of the season to harmonize soils by focusing on manures and water; Utilize and/or adapt to your resources and carefully manage the crop/environment complex; Integrate perceptions of the agronomic truths while developing one's skillfulness; Pass down the farming arts (knowing, predicting, and operating) from generation to generation including your own innovations and sense and local indigenous knowledge.

\section{Acknowledgements}

We thank Dr. Shi He Xiao for encouragement and supporting, and Dr. Sadras VO for reading the original manuscript and suggestions. We are grateful to Dr. Fred Magdoff, University of Vermont plant and soil science professor emeritus, for discussion and revision of the manuscript.

\section{References}

Angus J. F., Herwaarden A. F. (2001). Increasing water use and water use efficiency in dryland wheat. Agronomy Journal, 93, 290-298. http://dx.doi.org/10.2134/agronj2001.932290x

Li H. Z. (1983). An Available policy of Improving the Total yield of Wheat of Shanxi. Journal of Shanxi Agricultural University, 3(1), 1-9.

Magdoff F. R. (1993). Building soils for better crops: organic matter management. Univ. of Nebraska Press. Lincoln, Nebraska.

Pan X. L. (1982). A preliminary study on winter wheat root configurations and its effects on the grain yields. Journal of Shanxi Agricultural University, 2(1), 36-51.

Pan X. L. (1997a). Demographics of wheat and alfalfa root configurations on the Loess Plateau. Triticale crops, 17(1), 32-35.

Pan X. L. (1997b). Experiment on Cotton Cultivation method of "Nutrient Columns" on the Loess Plateau. Agricultural Research in the Arid Areas, 15(2), 44-48.

Sadras V. O., Angus J. F. (2006). Benchmarking water-use efficiency of rainfed wheat in dry environments. Australian Journal of Agricultural Research, 57, 847-856. http://dx.doi.org/10.1071/AR05359

Soothill W. E. (1924). Timothy Richard of China: seer, statesman, missionary \& the most disinterested adviser the Chinese ever had. Seeley Service, London.

Xiao J. Z. (1986). Drilling soil holes-A method for controlling run-off of water and soil in the loess plateau. Agricultural Research in the Arid Areas, 4(2), 1-8. 
Table 1. Yield, Precipitation, Soil Water (5 210 cm depth), Evaporation, EvapoTranspiration, and Water Use Efficiency at BeiZhang village, 1983-2009

\begin{tabular}{|c|c|c|c|c|c|c|c|c|c|c|c|}
\hline Crop year & $\begin{array}{l}\text { Yield } \\
\text { kgha }^{-1}\end{array}$ & $\begin{array}{c}{ }^{\mathrm{a}} \mathrm{WUE} \\
\mathrm{kgha}^{-1} \mathrm{~mm}^{-1}\end{array}$ & $\begin{array}{l}{ }^{{ }^{b}} P_{F} \\
\mathrm{~mm}\end{array}$ & $\begin{array}{c}{ }^{\mathrm{c}} \mathrm{S}_{\mathrm{SW} 210} \\
\mathrm{~mm}\end{array}$ & $\begin{array}{l}{ }^{\mathrm{d}} \mathrm{E}_{\mathrm{F}} \\
\mathrm{mm}\end{array}$ & $\begin{array}{l}{ }^{\mathrm{e}} \mathrm{PS} \\
\mathrm{mm}\end{array}$ & $\begin{array}{c}{ }^{\circ} \mathrm{PSE} \\
\%\end{array}$ & $\begin{array}{l}{ }^{g} \mathrm{P}_{\mathrm{G}} \\
\mathrm{mm}\end{array}$ & $\begin{array}{l}{ }^{\mathrm{h}} \mathrm{P}_{\mathrm{M}} \\
\mathrm{mm}\end{array}$ & $\begin{array}{c}{ }^{\mathrm{i}} \mathrm{H}_{\mathrm{SW} 210} \\
\mathrm{~mm}\end{array}$ & $\begin{array}{l}{ }^{\mathrm{j}} \mathrm{ET} \\
\mathrm{mm}\end{array}$ \\
\hline $1982 \sim 1983$ & 1553 & 5.03 & 498.2 & 372.8 & 347.1 & 151.1 & 30.3 & 271.0 & 134.1 & 335.3 & 308.5 \\
\hline $1983 \sim 1984$ & 1658 & 3.29 & 423.8 & 453.8 & 305.3 & 118.5 & 28.0 & 298.8 & 51.5 & 248.5 & 504.1 \\
\hline $1984 \sim 1985$ & 2010 & 4.92 & 430.6 & 442.8 & 236.4 & 194.2 & 45.1 & 210.7 & 105 & 245.2 & 408.3 \\
\hline $1985 \sim 1986$ & 2625 & 7.17 & 389.3 & 430.8 & 203.6 & 185.7 & 47.7 & 204.0 & 35.8 & 268.8 & 366.0 \\
\hline 1986 1987 & 900 & 3.99 & 129.8 & 246.8 & 151.8 & -22 & -16.9 & 228.4 & 52 & 249.6 & 225.6 \\
\hline 1987 1988 & 2408 & 7.33 & 267.0 & 306.3 & 210.3 & 56.7 & 21.2 & 256.9 & 54.1 & 234.6 & 328.6 \\
\hline 1988 1989 & 3263 & 9.39 & 409.7 & 392.6 & 251.7 & 158 & 38.6 & 183.2 & 24.7 & 228.3 & 347.5 \\
\hline 1989 1990 & 1635 & 4.12 & 268.8 & 315.3 & 181.8 & 87 & 32.4 & 307.5 & 64.9 & 225.9 & 396.9 \\
\hline $1990 \sim 1991$ & 1748 & 5.32 & 207.8 & 287.3 & 146.4 & 614 & 29.6 & 273.9 & 44.3 & 232.9 & 328.3 \\
\hline 1991 1992 & 1478 & 6.70 & 178.5 & 282.4 & 129.1 & 49.4 & 27.7 & 168.5 & 43.7 & 230.3 & 220.5 \\
\hline 1993 1994 & 2858 & 10.01 & 261.2 & 301.1 & 237.7 & 23.5 & 9.0 & 230.9 & 3.4 & 246.6 & 285.4 \\
\hline 1996 1997 & 3923 & 10.21 & 430.0 & 391.7 & 239.2 & 190.8 & 44.4 & 196.2 & 12.2 & 203.8 & 384.2 \\
\hline 1998 1999 & 2325 & 5.71 & 368.3 & 434.9 & 179.6 & 188.7 & 51.2 & 225.2 & 106.6 & 253.0 & 407.1 \\
\hline 1999 2000 & 3023 & 8.31 & 241.4 & 343.6 & 150.8 & 90.6 & 37.5 & 172.0 & 13.2 & 151.7 & 363.9 \\
\hline 2000 2001 & 810 & 2.84 & 155.1 & 234.2 & 72.6 & 82.6 & 53.2 & 223.5 & 8.8 & 172.4 & 285.3 \\
\hline 2001 2002 & 1718 & 5.45 & 275.0 & 292.4 & 155.1 & 120 & 43.6 & 233.1 & 93.7 & 210.6 & 314.9 \\
\hline $2002 \sim 2003$ & 2625 & 7.53 & 271.7 & 319.6 & 162.7 & 109 & 40.1 & 237.2 & 61 & 208.0 & 348.8 \\
\hline 2003 2004 & 3563 & 6.07 & 486.8 & 442.2 & 252.6 & 234.2 & 48.1 & 400.6 & 61 & 256.3 & 586.6 \\
\hline 2004 2005 & 1395 & 5.07 & 264.1 & 320.1 & 200.2 & 63.9 & 24.2 & 139.8 & 34.1 & 184.9 & 275.0 \\
\hline $2005 \sim 2006$ & 2085 & 6.26 & 201.9 & 227.8 & 159.0 & 42.9 & 21.3 & 275.7 & 65.2 & 170.6 & 332.9 \\
\hline 2006 2007 & 1875 & 5.90 & 272.7 & 259.7 & 183.7 & 89 & 32.7 & 181.2 & 19.1 & 123.3 & 317.6 \\
\hline 2007 2008 & 2670 & 8.41 & 322.1 & 278.0 & 167.4 & 154.7 & 48.0 & 192.3 & 32.5 & 152.9 & 317.4 \\
\hline 2008 2009 & 960 & 4.21 & 185.2 & 177.3 & 160.8 & 24.4 & 13.2 & 285.6 & 142.1 & 234.6 & 228.3 \\
\hline $\mathrm{n}$ & 23 & 23 & 23 & 23 & 23 & 23 & 23 & 23 & 23 & 23 & 23 \\
\hline mean & 2135.13 & 6.23 & 301.70 & 328.41 & 195.00 & 106.7 & 32.61 & 234.62 & 54.913 & 220.35 & 342.68 \\
\hline s.d. & 841.08 & 2.06 & 107.67 & 78.72 & 60.14 & 66.3 & 16.22 & 57.39 & 38.692 & 46.15 & 84.29 \\
\hline s.e. & 175.38 & 0.43 & 22.45 & 16.41 & 12.54 & 13.83 & 3.38 & 11.97 & 8.0679 & 9.62 & 17.58 \\
\hline c.v. & 0.3939 & 0.3305 & 0.3569 & 0.2397 & 0.3084 & 0.621 & 0.4974 & 0.2446 & 0.7046 & 0.2095 & 0.2460 \\
\hline skewness & 0.3723 & 0.4157 & 0.3291 & 0.1308 & 0.6547 & 0.115 & -1.3291 & 0.9727 & 0.8553 & -0.0132 & 1.1479 \\
\hline kurtosis & -0.4511 & -0.5353 & -0.9688 & -0.8943 & 1.0108 & -0.73 & 2.6148 & 1.8031 & 0.1097 & 0.8871 & 2.3345 \\
\hline
\end{tabular}

Note: $\quad{ }^{\mathrm{a}} \mathrm{WUE}=\underline{\mathbf{W}}$ ater $\underline{\text { Use }}$ Efficiency (Yield/ET) $\quad{ }^{\mathrm{b}} \mathrm{P}_{\mathrm{F}}=$ Precipitation during the Fallow period

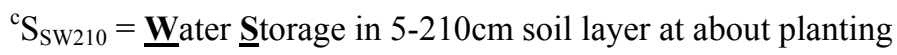

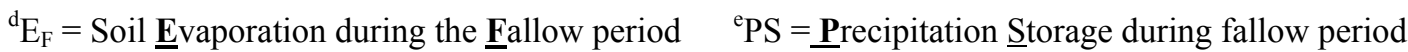

${ }^{\mathrm{f}} \mathrm{PSE}=\underline{\text { Precipitation }} \underline{\text { Storage }} \underline{\mathbf{E} f f i c i e n c y}$

${ }^{\mathrm{g}} \mathrm{P}_{\mathrm{G}}=$ Precipitation during the Growing season $\quad{ }^{\mathrm{h}} \mathrm{P}_{\mathrm{M}}=$ Precipitation in $\underline{\text { May }}$

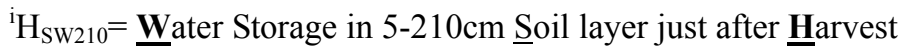

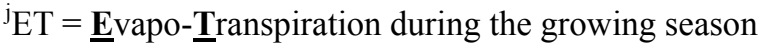



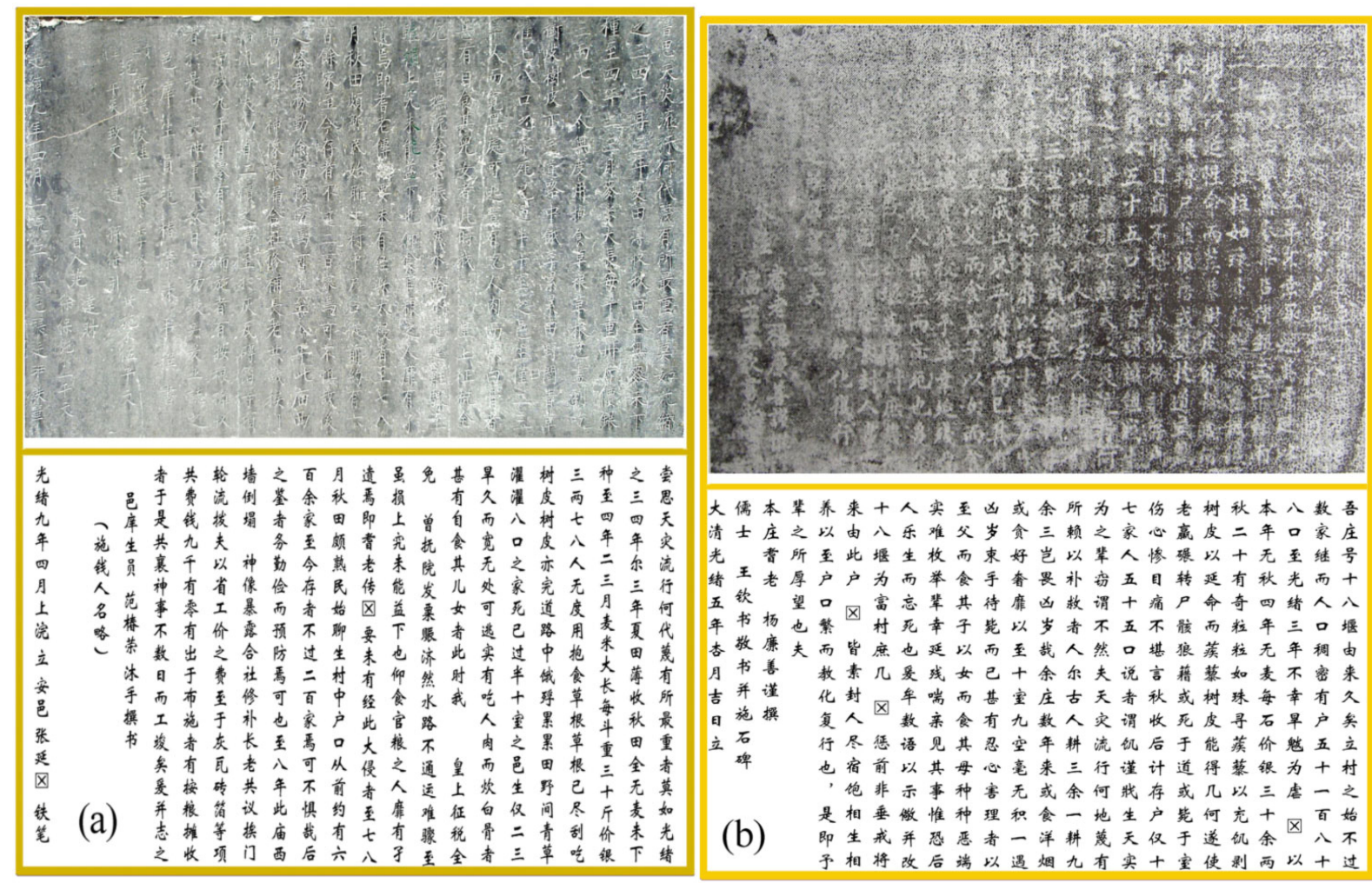

大偊本荤养来十人实至凶或余所为七伤老树秋本八数吾 清士庄之以由八乐难父岁食三赖之家心竟皮二年。家庄 光耆所至此嘎生枚而束好岂以辈人惨理以十无至继号 绪王老厚户户为而举食手营畏补荌五目转延有秋光而十 五钦望口区富忘辈其待鹰凶救谓十痛 $\boldsymbol{P}$ 命奇四绪人八 年书杨也繁区村死幸子垁以岁者不五不骹而粒年三口殹

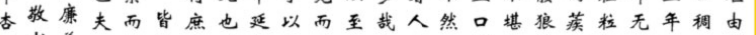
月书善教素几晏残女已十余尔夫说言藉蔡如麦不密来 吉并谨化封区车喘而基室庄古天者秋或树珠每幸有久 日施㩫复人区数亲食有九数人灾谓收死皮寻石早户矣 立石行尽恁语见其忍空年耕流饥后于能薮价勉五立 也宿前以其母心毫来三行谨计道得苇银为十村 , 饱非示事种害无或余何战存或几以三虐一之

（b）是相垂制惟种理积食一地生户觜何充十区而恶者一始 予相将改后端以遇烟九有实十害使剥两以十过

Figure 1. Village stone inscriptions carved following the famine of 1877 1878

(a) Ducun village, WanRong County, 1883 (more than 400 out of the total 600 households in the village died during the famine)

(b) Shibayan village, WenXi county, 1879 (133 out of the total 188 persons in the village died during the famine)

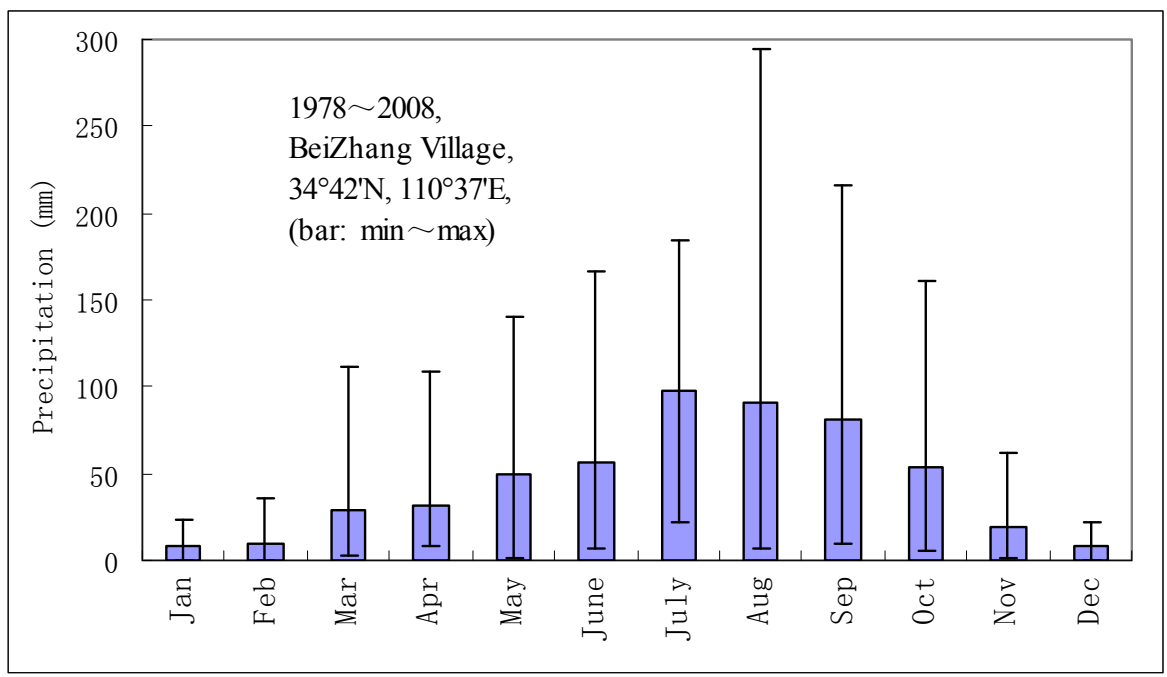

Figure 2. Average (column), maximum and minimum (line with bars) monthly precipitation during 1978 to 2008 at the study site 


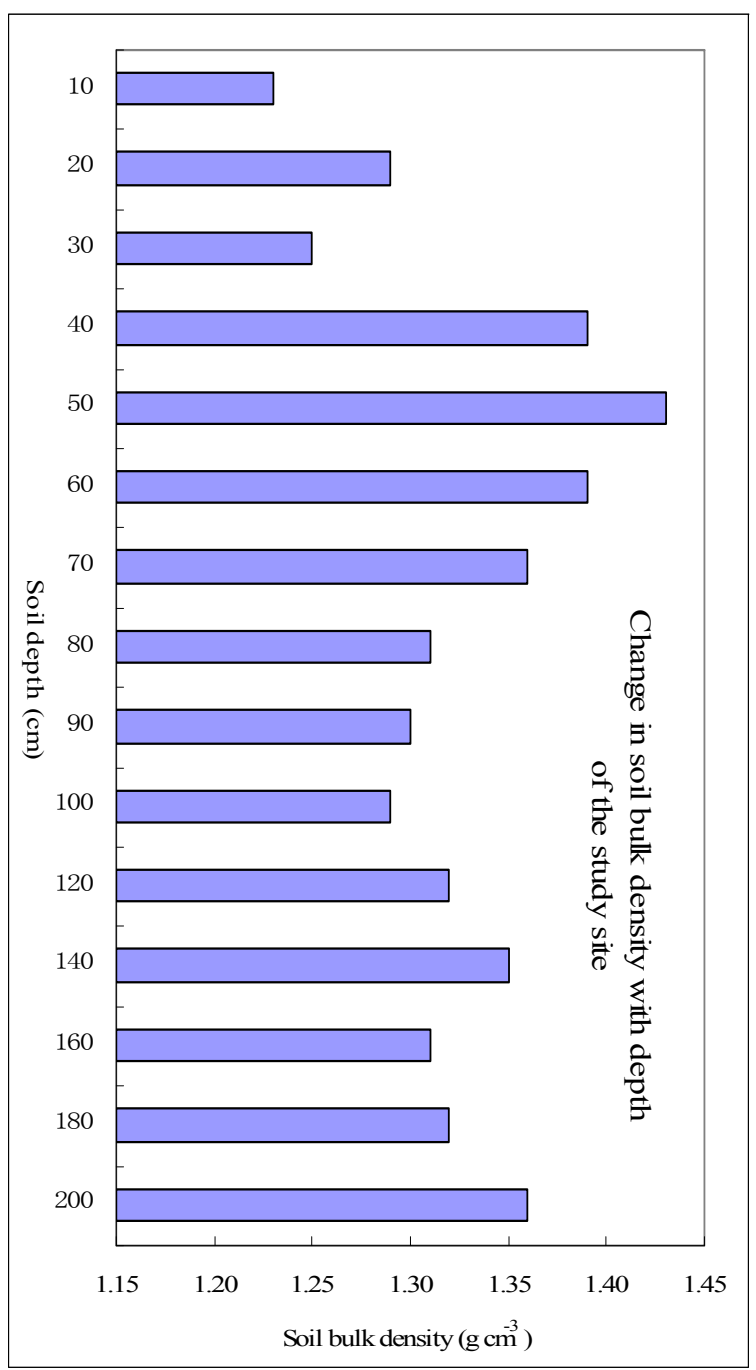

Figure 3. Change in soil bulk density with depth of the trial land 


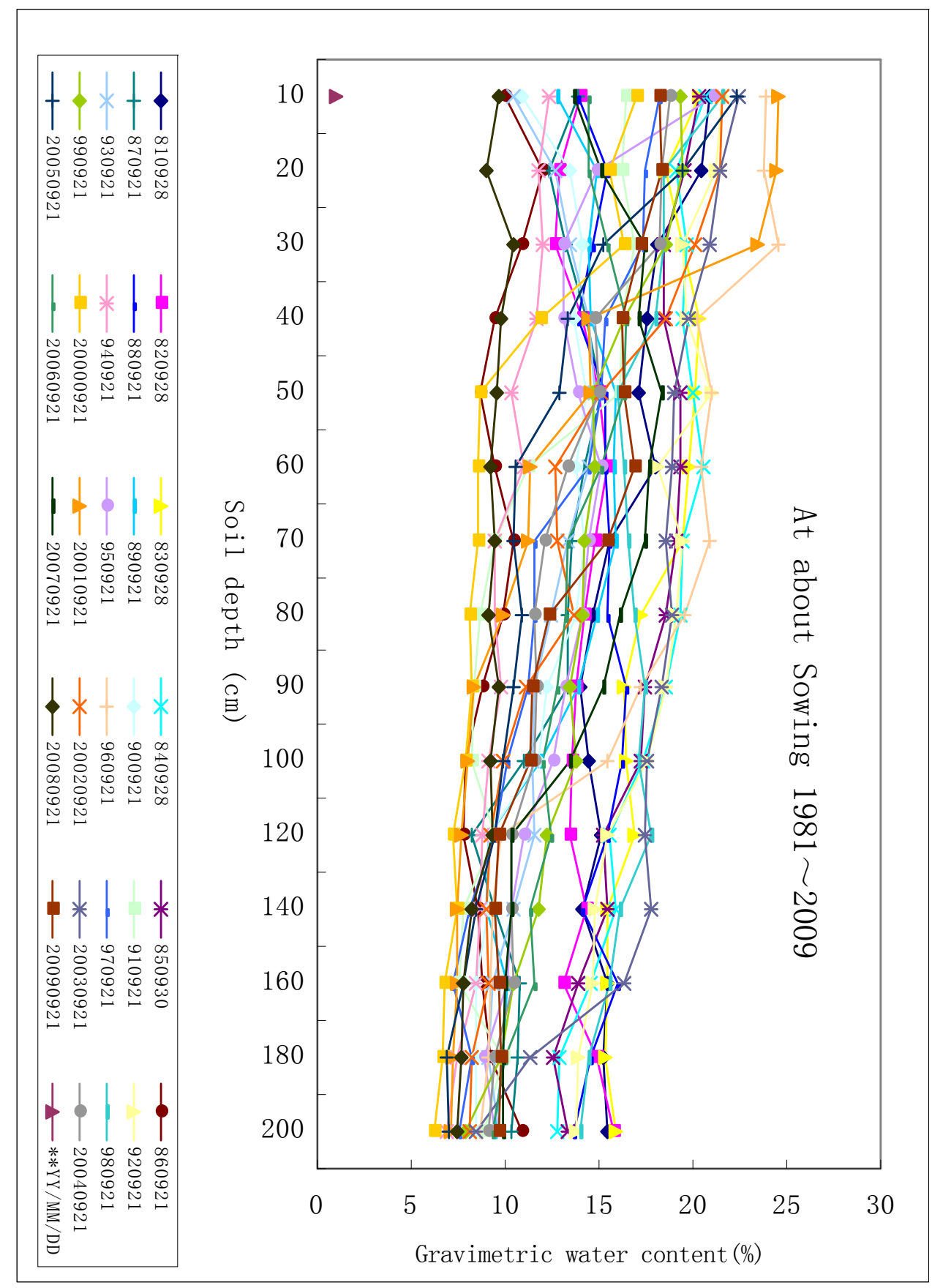

Figure 4. Change in gravimetric water content (\%) with depth of the trial land at about sowing (1983 2009) 


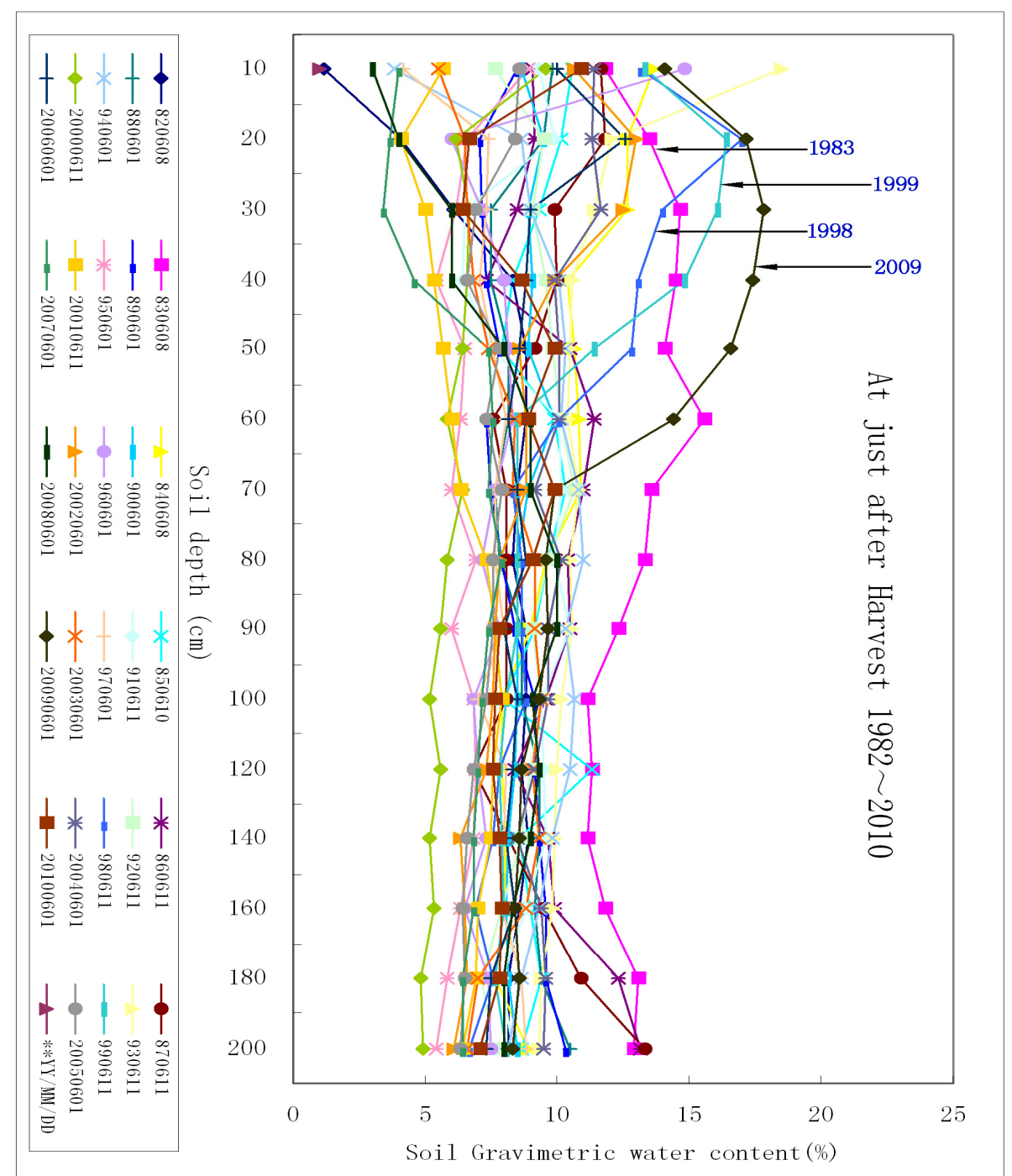

Figure 5. Change in gravimetric water content (\%) with depth of the trial land at just after harvest (1983 2009)

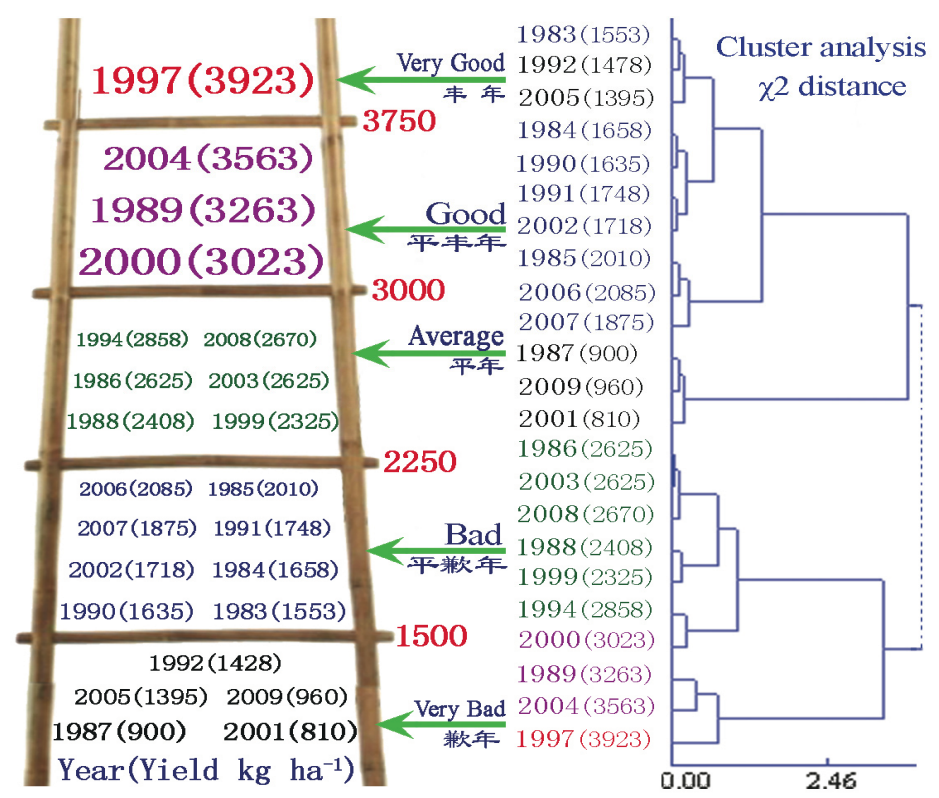

Figure 6. Cluster analysis and classification of the eco-niche-yields 


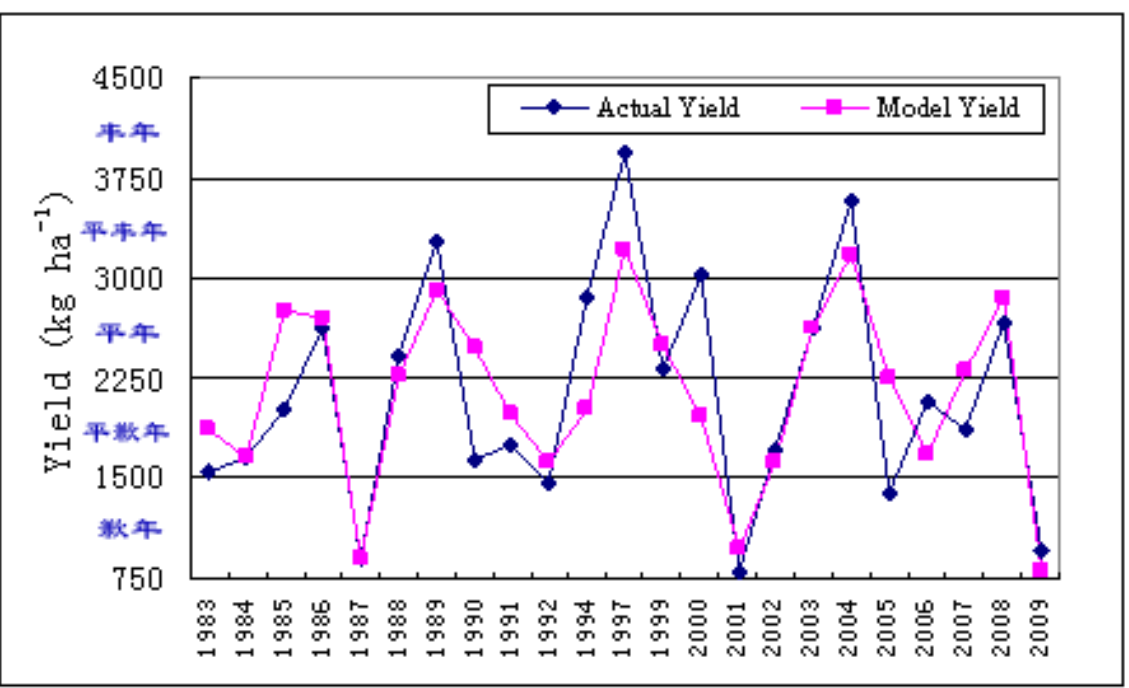

Figure 7. Yields estimated by regression equation model and measured yields $\mathbf{Y}=43.04 \mathbf{S}_{\mathbf{S W} 210}+41.02 \mathbf{P}_{\mathbf{F}}{ }^{2}-0.1301 \mathbf{S}_{\mathbf{S W} 210}{ }^{2}+0.1295 \mathbf{P}_{\mathbf{F}} * \mathbf{S}_{\mathbf{S W}_{210}}-41.09 \mathbf{P}_{\mathbf{F}} * \mathbf{E}_{\mathbf{F}}-41.06 \mathbf{P}_{\mathbf{F}} * \mathbf{P S}-4681.7$ $\left(\mathrm{R}=0.8148, \mathrm{R}^{2}=0.6639, \mathrm{p}=0.0036\right)$

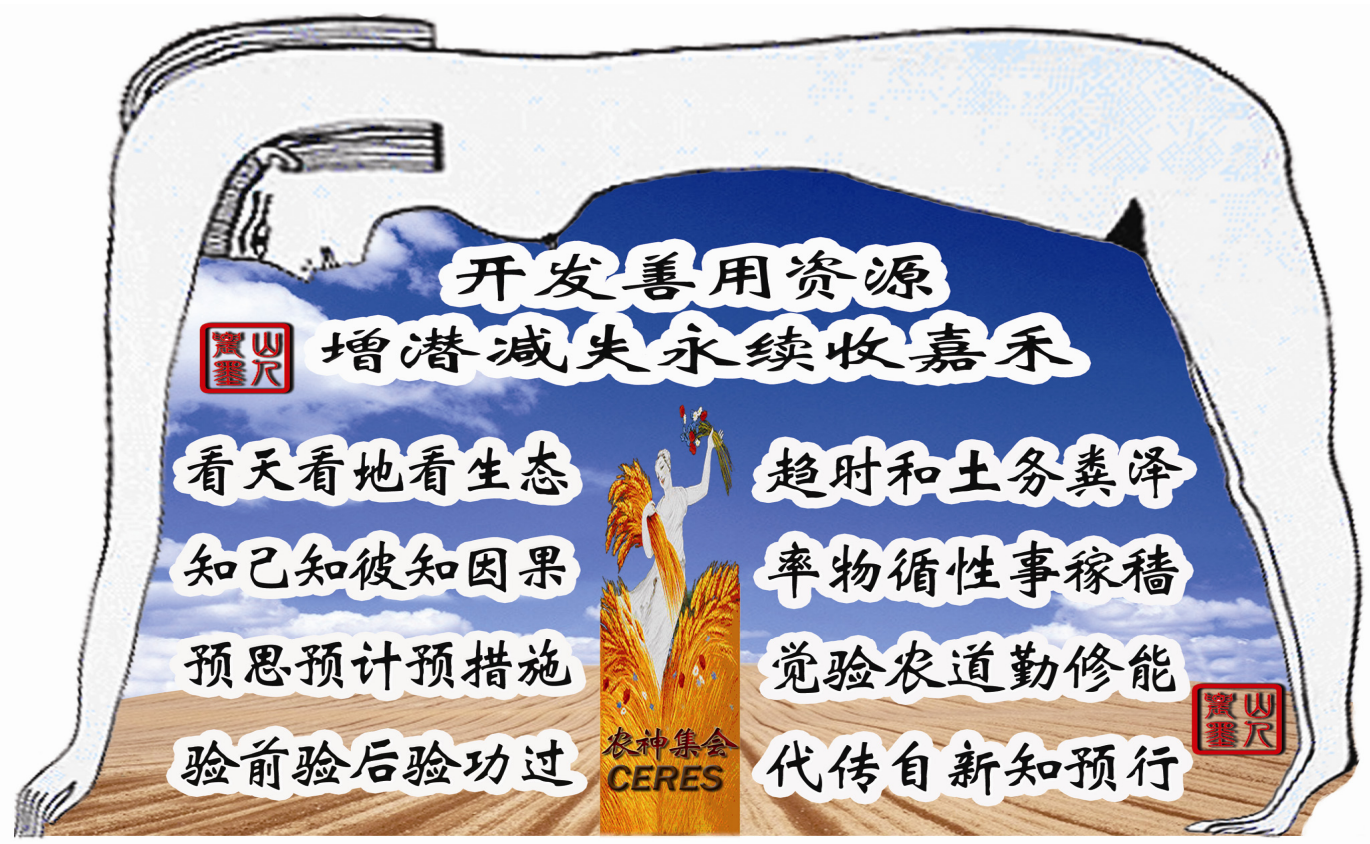

Figure 8. Chinese characters for crop production logos 